\title{
Influência da temperatura e do fotoperíodo na germinação in vitro de escleródios de Botrytis squamosa, agente etiológico da queima das pontas da cebola
}

\author{
Leandro Luiz Marcuzzo ${ }^{1}$, Cristiano Riscarolli ${ }^{1}$
}

${ }^{1}$ Instituto Federal Catarinense - IFC/Campus Rio do Sul, CP 441, 89.163-356, Rio do Sul, SC, Brasil

Autor para correspondência: Leandro Luiz Marcuzzo (leandro.marcuzzo@ifc.edu.br)

Data de chegada: 26/09/2017. Aceito para publicação em: 27/03/2018.

$10.1590 / 0100-5405 / 185816$

A queima das pontas da cebola causada por Botrytis squamosa (Walker) é caracterizada como a principal doença foliar na fase de muda da cultura. Os sintomas se manifestam nas folhas por meio de manchas esbranquiçadas, dispostas inicialmente de forma isolada e não esporulante. Porém o sintoma característico de maior dano na planta é a queima foliar, ocorrendo do ápice para a base da folha, onde se observa intensa esporulação com aspecto translúcido sobre a parte necrosada da folha (3). Uma das fontes primárias de inóculo são os escleródios do patógeno e trabalhos ligados a epidemiologia do inóculo primário da doença exigem o conhecimento prévio das condições ambientais necessárias para o inicio da epidemia, já que pesquisas relacionadas à queima das pontas ainda são escassas. Para tanto, o conhecimento da biologia do patógeno é de grande importância para compreender o desenvolvimento da doença no campo e o seu manejo. Diante disso, este trabalho teve como objetivo avaliar em condições in vitro a influência da temperatura e do fotoperíodo na germinação de escleródios de $B$. squamosa. O trabalho foi realizado no Laboratório de Microbiologia e Fitopatologia do Instituto Federal Catarinense - IFC/Campus Rio do Sul em experimento com delineamento inteiramente casualizado com cinco repetições. Os escleródios foram obtidos através da técnica de produção em palha seca de cebola conforme descrito por Marcuzzo et al. (2). Os escleródios passaram por assepsia em álcool 70\% e hipoclorito de sódio $1 \%$ por 1 minuto respectivamente em cada agente de assepsia e posteriormente em uma lavagem em água estéril para retirada dos agentes assépticos. Dez escleródios foram distribuídos equidistantes em cada placa de Petri contendo BDA com composto de suco de escama de cebola a $10 \%$ para favorecer a germinação dos escleródios e em seguida incubados em câmera de germinação do tipo B.O.D. (Demanda Biológica de Oxigênio) nas temperaturas de $5,10,15,20,25$, e $30^{\circ} \mathrm{C}$

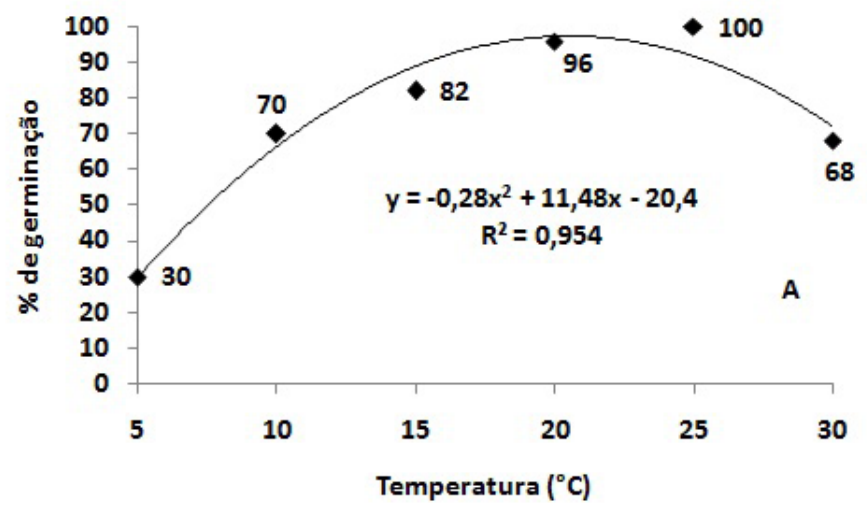

$\left( \pm 1^{\circ} \mathrm{C}\right)$ no escuro. Diariamente era feito a contagem dos escleródios germinados em cada tratamento, até que um deles apresentasse a germinação de todos os escleródios. Isto ocorreu aos três dias nas placas incubadas na temperatura de $25^{\circ} \mathrm{C}$. A partir da obtenção da temperatura ótima de germinação, repetiu-se o ensaio seguindo a mesma metodologia acima, incubando-se a $20,5^{\circ} \mathrm{C}$ com fotoperíodos de $0,6,12$, 18 e 24 horas, a fim de avaliar o fotoperíodo favorável a germinação dos escleródios. Verificou-se que a temperatura influenciou na germinação dos escleródios, tendo apresentado melhor desenvolvimento entre as temperaturas de 20 e $25^{\circ} \mathrm{C}$ (Figura 1A), onde germinaram em média de 96 e $100 \%$ dos escleródios respectivamente. Utilizando a equação gerada pela curva $\left(y=-0,28 \mathrm{x}^{2}+11,48 \mathrm{x}-20,4 ; \mathrm{R}^{2}=0,954\right)$ (Figura 1A) obtém-se a temperatura ideal de $20,5^{\circ} \mathrm{C}$ para a germinação de escleródios de $B$. squamosa. A temperatura da germinação de escleródios no presente trabalho esta acima dos $16-18^{\circ} \mathrm{C}$ utilizada no trabalho de Ellerbork \& Lorbeer (1) para a germinação de escleródios de B. squamosa provenientes do solo. Em relação a formação de escleródios em diferentes fotoperíodos observou-se a formação de uma linha polinomial (Figura 1B), que através da equação $y=-0,059 \mathrm{x}^{2}-1,661 \mathrm{x}+88,51 \quad\left(\mathrm{R}^{2}=0,919\right)$, verificou-se que o fotoperíodo mais favorável ao desenvolvimento é de 18 horas de luz com $100 \%$ dos escleródios germinados quando comparado com zero horas de luz que obteve apenas $88 \%$, porém pouco expressiva a diferença $(12 \%)$ do fotoperíodo ao se comparar com a temperatura. As informações obtidas em relação à temperatura e o fotoperíodo na germinação de escleródios de $B$. squamosa permitem um maior conhecimento da biologia do agente causal queima das pontas da cebola, auxiliando no entendimento da epidemiologia e suporte para manejo da doença no campo. Os resultados obtidos servirão de suporte na elaboração de um sistema de previsão da doença.

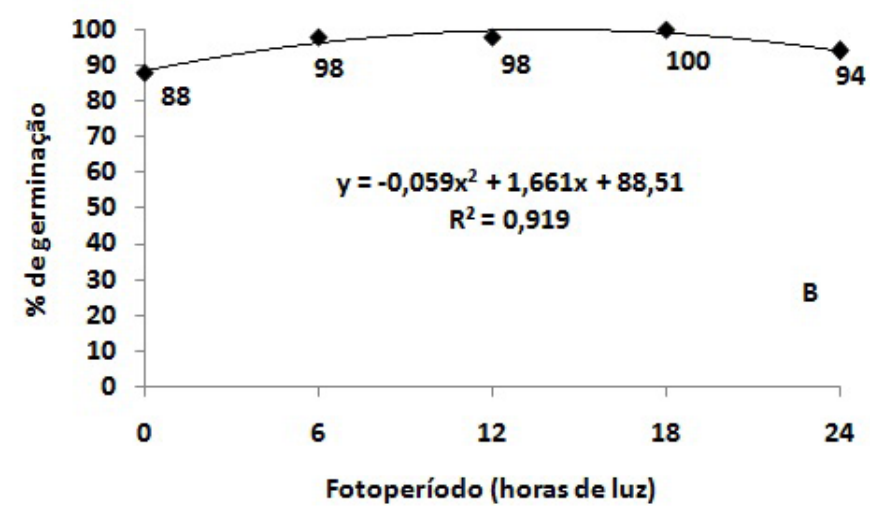

Figura 1. Curva de germinação de escleródios in vitro de Botrytis squamosa em diferentes temperaturas (A) e fotoperíodos (B). IFC/Campus Rio do Sul, 2017. 


\section{REFERÊNCIAS}

1. Ellerbrock, L.A.; Lorbeer, J.W. Survival sclerotia and conidia of Botrytis squamosa. Phytopathology, St. Paul, v.67, n.2, p.219-225, 1977.

2. Marcuzzo, L.L.; Nascimento, A.; Kotkoski, B. Technique for inducing Botry- tis squamosa sclerotium formation in vitro. Summa phytopathologica, Botucatu, v.43, n.3, p.251, 2017.

3. Töfoli, J.G.; Ferrari, J.T.; Domingues, R.J.; Nogueira, E.M.C. Botrytis sp. em espécies hortícolas: hospedeiros, sintomas e manejo. Biológico, São Paulo, v.73, n.1, p.11-20, 2011. 